TT Revista del instituto de Ciencias

$1 \bigcup \begin{aligned} & \text { JURÍDICAS DE PUEBLA, MÉXICO, AÑO V } \\ & \text { NO. 28, JULIO-DICIEMBRE DE 2011, PP. } 123-159\end{aligned}$

\title{
El control judicial interno de convencionalidad*
}

\section{The Conventional Internal Control Court}

\author{
Sergio García Ramírez**
}

\section{RESUMEN}

La Corte Interamericana de Derechos Humanos ha elaborado el concepto de "control de convencionalidad", que recientemente fue acogido por la doctrina y figura en la jurisprudencia de varios paises americanos, entre ellos México. El autor de este artículo plantea alternativas para el control judicial interno de convencionalidad. En este ámbito puede figurar una "cuestión de convencionalidad" (similar a la "cuestión de constitucionalidad"), que implica la consulta sobre convencionalidad de normas elevada a un tribunal superior competente para atender y resolver la consulta. De esta manera se sirve a la armonización de la jurisprudencia nacional y se evita la multiplicación de decisiones judiciales discrepantes.

PALABRAS CLAVE: Control judicial interno de convencionalidad, Cuestión de convencionalidad, responsabilidad internacional del Estado.

\begin{abstract}
The Inter-American Court of Human Rights has developed the concept of "control of conventionality", which was recently hosted by the doctrine and jurisprudence contained in several Latin American countries, including Mexico. The author of this article discusses alternatives to the internal judicial conventionality. In this area may include a "matter of conventionality" (similar to the "constitutional question"), which involves consultation on standards conventionality elevated to a higher court competent to hear and resolve the query. This will serve to harmonize national case law and prevents the proliferation of conflicting court decisions.
\end{abstract}

KEY WORDS: Domestic judicial control of conventionality, conventionality question of international responsibility of the State.

\footnotetext{
* Recibido: 3 de agosto de 2011. Aceptado: 25 de agosto de 2011.

** Investigador en el Instituto de Investigaciones Jurídicas de la unam, México (sgrunam@gmail.com).
} 
SERGIO GARCÍA RAMÍREZ

\section{Sumario}

1. Advertencia

2. El control interno de convencionalidad: perfil y características

3. La Corte Interamericana: circunstancia y actualidad

4. Integración y fuerza del derecho internacional (interamericano) de los derechos humanos

5. La responsabilidad unitaria del Estado

6. Imputación al Estado

7. El control de convencionalidad en la doctrina jurisprudencial de la CorteiDH

8. Control interno de convencionalidad y obligaciones generales de los Estados (artículos $1^{\circ}$

y $\left.2^{\circ} \mathrm{CADH}\right)$

9. Control interno de convencionalidad derivado del carácter subsidiario de la jurisdicción

internacional y de la "vocación" institucional de la CorteIDH

10. Control interno de convencionalidad y debido proceso. El juez natural

11. Métodos para el control: concentrado y difuso

12. Posición de la Suprema Corte de Justicia de México

\section{Advertencia}

Entre los temas sobresalientes por su actualidad y trascendencia, que guardan relación con el sistema tutelar de los derechos humanos en el doble plano nacional e internacional, figura el denominado "control de convencionalidad", de carácter judicial, al que en este trabajo me referiré, más precisamente, como "control interno de convencionalidad".

El control de convencionalidad en su doble dimensión: externo (propio, original) e interno, ha sido objeto de un largo y sólido desarrollo en la jurisprudencia de la Corte Interamericana de Derechos Humanos (en adelante CorteiDH) desde que me ocupé específicamente de este asunto en votos particulares a los que adelante aludiré. Hoy es tema de consideración destacada en la jurisprudencia de la Suprema Corte de Justicia de la Nación - precisamente a propósito de la decisión adoptada por la Corte Interamericana en el caso Radilla Pachecocomo primera y trascendental etapa en la tarea de conferir orden y rumbo a estas cuestiones en el ámbito del derecho interno. No es conveniente que algunos progresos del sistema jurídico nacional se hallen desprovistos de cauce legal, como ha ocurrido en otras materias: así, jurisdicción para menores en conflicto con la ley penal, jurisdicción para la ejecución de penas, por ejemplo.

Por el interés que suscita el control de convencionalidad, proyectado sobre nuevos rumbos del orden jurídico mexicano, me ha parecido conveniente incluir este capítulo en la nueva edición de La Corte Interamericana de Derechos $\mathrm{Hu}$ - 
manos. No pretendo hacer ahora un examen detallado del control interno de convencionalidad, sino ofrecer un panorama sintético a la luz de sus fundamentos en el derecho interamericano de los derechos humanos y de los elementos que lo han caracterizado en la jurisprudencia de aquella Corte, fuente para la consideración inicial por parte de la Suprema Corte de Justicia de nuestro país.

Para los fines del presente comentario, citaré con alguna extensión -y para ello solicito la indulgencia del lector: no es mi costumbre incluir transcripciones amplias en el texto principal de mis artículos- algunos párrafos de mis votos particulares correspondientes a sentencias emitidas en la CorteidH, que se hallan en el origen de la reflexión jurisprudencial internacional, como lo han manifestado, con objetividad que reconozco, varios tratadistas de la materia: Juan Carlos Hitters, Ernesto Rey Cantor, Néstor SagüÉs y Giuseppe de Vergottinl, entre los extranjeros, y algunos estudiosos mexicanos, como Eduardo Ferrer Mac-Gregor.

También invocaré las referencias que hago en libros de los que soy coautor, recientemente publicados bajo el doble signo de la Editorial Porrúa y la UNAM (Instituto de Investigaciones Jurídicas), así: La reforma constitucional sobre derechos humanos (2009-2011) (coautora: Julieta MoRAles SÁnchez) y México ante la Corte Interamericana de Derechos Humanos. Decisiones y transformaciones (coautor: Mauricio del TORo HUERTA), ambos aparecidos en el segundo semestre de 2011. Y daré cuenta de las determinaciones centrales acogidas por la Suprema Corte de Justicia de la Nación entre julio y septiembre de 2011, cuando sometió a examen diversas implicaciones de la sentencia de la CorteidH correspondiente al caso Radilla Pacheco, y se hizo la publicación correspondiente en el Diario Oficial de la Federación.

Debo decir, por lo demás, que antes de ahora he abordado con algún detenimiento estas cuestiones en conferencias sustentadas en diversos foros jurídicos nacionales; por ejemplo, las xil Jornadas de Actualización en Derecho Procesal, organizadas por el Colegio de Profesores de Derecho Procesal "Dr. Cipriano Gómez Lara”, el Instituto Mexicano de Derecho Procesal y el Colegio de Profesores de Derecho Procesal de la Facultad de Derecho de la Universidad Nacional Autónoma de México (México, 24 de junio de 2011), y el Seminario sobre las

Reformas Constitucionales en Materia de Derechos Humanos y Amparo, de la Barra Mexicana. Colegio de Abogados (México, 7 de octubre del mismo año).

\section{El control interno de convencionalidad: perfil y características}

Con el propósito de plantear adecuadamente -desde mi punto de vista- el desarrollo de esta materia, estimo conveniente apuntar desde ahora ciertos ele- 
mentos que permiten la aproximación al control interno de convencionalidad, a sabiendas de que algunos pudieran quedar incluidos, con igual o mayor razón, en las conclusiones del trabajo. Valgan, pues, como hipótesis de partida y como adelanto de la tesis que resulta de mis reflexiones.

El control propio, original o externo de convencionalidad recae en el tribunal supranacional llamado a ejercer la confrontación entre actos domésticos y disposiciones convencionales, en su caso, con el propósito de apreciar la compatibilidad entre aquéllos y éstas - bajo el imperio del derecho internacional de los derechos humanos-, y resolver la contienda a través de la sentencia declarativa y condenatoria que, en su caso, corresponda. En definitiva, ese control incumbe, original y oficialmente, a la CorteidH cuando se trata de examinar casos de los que aquélla conoce y a los que aplica normas conforme a su propia competencia material. De ahí que haya aludido a un control propio, original o externo.

Ahora bien, cuando menciono el control interno de convencionalidad me refiero a la potestad conferida o reconocida a determinados órganos jurisdiccionales -0 a todos los órganos jurisdiccionales, como infra veremos- para verificar la congruencia entre actos internos -así, esencialmente, las disposiciones domésticas de alcance general: Constituciones, leyes, reglamentos, etcétera- con las disposiciones del derecho internacional (que en la hipótesis que me interesa reduciré a una de sus expresiones: el derecho internacional de los derechos humanos, y más estrictamente el derecho interamericano de esa materia).

De esa verificación, que obviamente implica un ejercicio de interpretación, provendrán determinadas consecuencias jurídicas: sustancialmente, la convalidación o la invalidación (obtenidas por distintos medios y con diferentes denominaciones) del acto jurídico doméstico inconsecuente con el ordenamiento internacional.

En principio -y en términos muy generales-, el proceso lógico de confrontación entre normas nacionales e internacionales no corre sólo a cargo de las autoridades jurisdiccionales -aunque en el presente estudio me ocuparé solamente de este supuesto-, sino que puede y debe ser cumplido igualmente por cualquier persona, y ciertamente por cualesquiera autoridades llamadas a promover, respetar, proteger y garantizar, en el espacio de sus atribuciones, los derechos humanos. Esto último destaca en el artículo $1^{\circ}$ constitucional, conforme a las novedades incorporadas en ese texto en 2011.

Dicho esto, reiteraré que el campo de mis reflexiones se reducirá al control de convencionalidad que realizan los juzgadores (al que se refirieron, originalmente, mis votos particulares ante la Corte Interamericana, al que aludió la jurisprudencia posterior de ésta y sobre el que se manifestaron las decisiones de la Suprema Corte de Justicia de la Nación entre julio y septiembre de 2011), una función que 
ofrece características muy cercanas a las que presenta el bien conocido control de constitucionalidad. El de convencionalidad posee, en el ámbito externo, un significado semejante al que caracteriza al de constitucionalidad en el interno.

En mi voto sobre el caso Trabajadores Cesados del Congreso vs. Perú. Aguado Alfaro y otros (24 de noviembre de 2006) cotejé nuevamente

[...] la función de los tribunales internacionales de derechos humanos con la misión de las cortes constitucionales internas. Éstas tienen a su cargo velar por el Estado de derecho a través del juzgamiento sobre la subordinación de actos de autoridades a la ley suprema de la nación. En el desarrollo de la justicia constitucional ha aparecido una jurisprudencia de principios y valores - principios y valores del sistema democrático- que ilustra el rumbo del Estado, brinda seguridad a los particulares y establece el derrotero y las fronteras en el quehacer de los órganos del Estado.

El control de convencionalidad es una expresión o vertiente de la recepción nacional, sistemática y organizada del orden jurídico convencional internacional (o supranacional). Constituye un dato relevante para la construcción y consolidación de ese sistema y ese orden, que en definitiva se traducen en el mejor imperio del Estado de derecho, la vigencia de los derechos y la armonización del ordenamiento regional interamericano (puesto que me estoy refiriendo al control ejercido con base en instrumentos de esta fuente) con vistas a la formación de un ius commune del mismo alcance geográfico-jurídico. Néstor SAGüÉs ha dicho, con buen fundamento, que "la doctrina del 'control de convencionalidad', bien instrumentada, puede ser una herramienta provechosa para asegurar la primacía del orden jurídico internacional de los derechos humanos, y edificar un ius commune en tal materia, en el área interamericana".

Es preciso, pues, colocar el control en este marco y enfilarlo a la procuración de ese desiderátum, que supera ampliamente las pretensiones insulares y las ocurrencias circunstanciales. La clara conciencia de estos extremos contribuirá a diseñar y orientar el control en los términos más convenientes.

Prosigamos este apunte de conceptos generales. El control se inscribe en un sistema (jurídico-político) construido a partir de voluntades soberanas, con sustento en valores y principios compartidos (que constan, explícita o implícitamente, en los documentos fundacionales del sistema: Declaración Americana de Derechos y Deberes del Hombre y Convención Americana sobre Derechos Humanos; además, otros instrumentos con semejante contenido); normas comunes (el corpus juris americano de los derechos humanos) y una instancia supranacional con poder de interpretación vinculante (la CorteıDH, sin olvido de la Comisión Interamericana, cuya misión orientadora no participa del carácter 
inequívocamente vinculante que tienen las determinaciones jurisdiccionales del tribunal).

En consecuencia, la figura del control de convencionalidad, oriunda de ese sistema y asociada a él, guarda relación estrecha con los datos o componentes que conforman el sistema. En otras palabras: no se aísla de las diferentes expresiones del mismo fenómeno del que forma parte y del que es tributario. Es preciso analizarla, encauzarla y valorarla en este conjunto.

El control de convencionalidad entraña la aplicación del orden supranacional, nacionalmente aceptado y colectivamente formulado, en lo que toca a definiciones de derechos y libertades, asignación de responsabilidades y consecuencias jurídicas de los hechos ilícitos contraventores de aquel orden. El control se acoge a lineamientos que le confieren congruencia en el examen de todas esas cuestiones. Además, representa esto mismo: congruencia, no ocurrencia con propósito puramente innovador o protagónico; puede ser el fruto de un activismo bien entendido, pero no podría (no debería) comprometerse con un activismo desbocado. Así las cosas, el control de constitucionalidad no dispersa ni atomiza, sino reúne y sistematiza.

En su propia vertiente, el control que ahora examino se halla al servicio de la justicia y la seguridad jurídica. Parece innecesario decirlo, pero es conveniente insistir en ello: no debe culminar en siembra de injusticia ni de inseguridad general o particular. Existe el riesgo de que así ocurra cuando se carece de encaminamiento razonable, preciso, sistemático, y aparecen, sin concierto, ensayos de control que no obedecen a un conocimiento profundo y una conducción armoniosa de la interpretación jurisdiccional en esta materia.

En el examen de estos temas surge un punto extensamente considerado por la jurisprudencia y la doctrina europea, e infrecuentemente abordado -deliberadamente- por la jurisprudencia y la doctrina americana: el margen nacional de apreciación. Desde luego, el control interno de convencionalidad supone cierto margen nacional de apreciación. Sería imposible excluirlo en la hipótesis -que adelante examinaré- de que no existan definiciones del tribunal supranacional o de que pudiera haber decisiones nacionales que brinden mejor protección al ser humano. Ahora bien, es preciso reconocer que en la generalidad de los casos este margen de apreciación -nacional y circunstancial: al amparo de las circunstancias del caso sub judice - se halla acotado por las definiciones del órgano supranacional de interpretación vinculante.

Cuando el tribunal nacional despliega el control de convencionalidad, en ausencia de definiciones supranacionales, las decisiones de aquél no tienen alcance erga omnes. Es decir, puede fijar criterios provisionales, inter partes, sujetos a control nacional inmediato (a través de un régimen de "cuestiones de 
inconvencionalidad", como adelante se mencionará, que constituye una alternativa atendible, entre otras) e invariablemente condicionados a definiciones supranacionales.

Diré, finalmente, que el control de convencionalidad, desplegado con seriedad, competencia y acierto, favorece y fertiliza el diálogo jurisprudencial (o bien, jurisdiccional) interno e internacional. Contribuye a erigir, detallar, enriquecer e impulsar la cultura jurídica común, conforme al proyecto favorecedor del ser humano y conductor del poder público.

No es conveniente ni realista pretender que todo el orden jurídico sea producto de una sola fuente internacional, con operación puramente endogámica, ciega y sorda a las incitaciones que surgen de las fuentes nacionales de reflexión y decisión. En el mismo sistema interamericano se cuenta con ejemplos -cada vez más numerosos y aleccionadores- sobre la racionalidad y los beneficios del diálogo jurisprudencial.

\section{La Corte Interamericana: circunstancia y actualidad}

Puesto que el control interno de convencionalidad en materia de derechos humanos trabajará, en buena medida, a partir de la jurisprudencia de la Corte Interamericana -órgano y jurisprudencia que aún no son suficientemente conocidos en nuestro medio-, parece conveniente proveer ciertos datos esenciales sobre ese tribunal, sin pretender examinar con detalle su origen, sus atribuciones y su desarrollo.

La CorteidH es una pieza esencial del denominado sistema interamericano de protección de los derechos humanos, que en su propio ámbito atiende a los objetivos que, en los suyos, han asumido otros sistemas anteriores o posteriores: el mundial, desde luego, a partir de la Declaración Universal de 1948; el europeo, con base en el Convenio de Roma de 1950, y el africano, que se sustenta en la Carta Africana de los Derechos Humanos y de los Pueblos - Carta de Banjul- de 1981. El sistema interamericano inició formalmente la marcha -lo que he llamado la "navegación americana", con destino compartido, pero itinerario, características y tiempos propios- en 1945, fecha de la Conferencia de Chapultepec sobre Problemas de la Guerra y de la Paz. Desde entonces ha cumplido tareas importantes y mostrado un apreciable desarrollo en sus diversos componentes: ideológico, normativo, subjetivo y judicial.

El componente ideológico-político del sistema -en rigor, su factor o raízreside en las convicciones compartidas acerca del papel del hombre, la sociedad y el Estado en la vida colectiva, que coloca a aquél en el centro de la escena y 
exalta la misión y la exigencia de la democracia. "Sociedad democrática" es un concepto central de ese componente ideológico-político del sistema, que tiene aplicación al tiempo de interpretar las normas y fijar el rumbo de la jurisprudencia. No podría ignorarlo el intérprete internacional; tampoco el juzgador nacional que interpreta y aplica textos internacionales.

Ese mismo concepto domina en el examen sobre el desenvolvimiento mismo del sistema y contribuye a advertir y apreciar los contrastes entre la situación que guarda hoy y la que hubo en cada una de las fechas clave dentro de la historia del sistema: 1945, mencionada; 1948, año de emisión de la Carta de la OEA y la Declaración Americana (previa, por varios meses, a la Universal; aquélla adoptada el 2 de mayo; la segunda el 10 de diciembre); 1969, oportunidad de la Convención Americana o Pacto de San José; 1978, inicio de la vigencia de esta Convención; 1999, año en que se produjo el último acto de reconocimiento estatal - hasta hoy - de la competencia contenciosa de la Corte Interamericana, y 2011, año en el que la jurisprudencia de la Suprema Corte de México -con algunos precedentes en nuestro país, y muchos en otros Estados- declara con el mayor énfasis la recepción nacional del derecho internacional de los derechos humanos.

En el examen sobre los vínculos entre democracia y derechos humanos hay que recordar los términos de la Carta Democrática Americana, de 2001, que destaca el inescindible binomio: democracia y derechos humanos. $Y$ también cabe mencionar la reafirmación de las soluciones democráticas y garantistas, incluso en situaciones de violencia extrema, como se desprende de la Convención Interamericana contra el Terrorismo, de 2002, y de la constante jurisprudencia de la Corte Interamericana acerca de la autotutela del Estado, la seguridad de la sociedad, el empleo admisible de la fuerza, el principio de legalidad y el debido proceso.

El componente normativo del sistema -corpus juris, que antes dije- permite examinar el tránsito desde la tierra baldía de 1945 hasta el punto al que ha llegado el desenvolvimiento del derecho internacional de los derechos humanos.

Es relevante analizar en este punto (análisis que escapará a los juzgadores llamados a ejercer el control de convencionalidad, así sea para los fines de interpretación de textos convencionales en congruencia con estándares internacionales) la composición de ese derecho de los derechos humanos, que no se constriñe a las fuentes bien sabidas de la costumbre internacional y los tratados (y convenciones especializadas y protocolos), sino abarca otros actos (infra, 4). En cada especie es preciso explorar la fuerza jurídica: del carácter meramente orientador o sugerente - sin perjuicio de la operación enérgica del principio pacta sunt servanda- a la eficacia vinculante: sea inter partes, sea erga omnes. 
El componente subjetivo del sistema corresponde a los diversos personajes que en él concurren: obviamente, los individuos -todos: en calidad de seres humanos, beneficiarios de la tutela general o especial; y en condición de víctimas, reclamantes ante instancias domésticas o externas- y los Estados: 34 miembros de la OEA, 24 partes en la Convención Americana, 21 -México entre ellos- aceptantes de la competencia contenciosa de la CorteidH. Veintiún Estados en cuya jurisdicción habitan 550 millones de seres humanos. Bajo el mismo rubro de componente subjetivo añadamos: sociedad civil y sus instituciones, y actores emergentes: academia, comunicadores sociales, ombudsman, defensores públicos.

El avance es muy estimable, aunque todavía nos hallemos lejos de la meta indispensable: admisión continental, total, que concrete el propósito consustancial a los derechos humanos, su apetito de universalidad, a saber: "derechos y jurisdicciones para todos". Por ahora, la jurisdicción interamericana se ha desplegado en un "espacio judicial (esencialmente) latinoamericano".

Finalmente, el componente judicial se concentra en la Corte Interamericana, depositaria de una jurisdicción madura. Aquélla ha definido con suficiente claridad -y con éxito, hasta el momento- su "vocación institucional" y creado una doctrina jurisprudencial cada vez más nutrida y aceptada, que acude a integrar el derecho interamericano de los derechos humanos.

La CorteidH es un tribunal permanente (ejerce su jurisdicción en forma ininterrumpida, sin perjuicio de que sus integrantes se reúnan materialmente en periodos de sesiones en San José o en otras ciudades de América) con vocación hacia los casos paradigmáticos, para la emisión de criterios jurisdiccionales que sean recibidos y multiplicados en el ámbito interno a través de diversos mecanismos de recepción. Uno de éstos es el control de convencionalidad.

Diré, de paso, que a mi juicio resulta evidente que la Corte Interamericana no podría ni debería asumir el conocimiento de un gran número de casos, sería impracticable y perturbador; su "oficio" es el conocimiento de grandes temas -frecuentemente ampliados con nuevas vertientes, perspectivas o aplicacionesa los que aportará soluciones que permearán los ordenamientos internos.

\section{Integración y fuerza del derecho internacional (interamericano) de los derechos humanos}

La idea y la práctica del control interno de convencionalidad descansan en la eficacia que se reconozca a los actos que integran el derecho internacional de los derechos humanos, puesto que se trata, precisamente, de acoger la fuerza de 
éstos en el ámbito nacional e imprimirles mayor o menor imperio. En la actualidad se ha generalizado - con decrecientes trincheras de resistencia- el valor de ese derecho internacional. De ahí la doble fuente de los derechos humanos, esto es, la dual composición del estatuto de los derechos fundamentales del hombre contemporáneo: interna e internacional.

Permítaseme recordar anteriores elaboraciones acerca de la recepción nacional del derecho internacional de los derechos humanos, fenómeno que tiene notable arraigo y en el que se enmarca el control de convencionalidad. Hay diversas expresiones (o "puentes", he dicho, caracterizando las vías de tránsito del orden internacional hacia el nacional, como antes aconteció desde éste hacia aquél) de la recepción interna a la que me refiero.

Ante todo, existe un "puente" constitucional que se ha tendido de manera insistente a través de reformas a la ley suprema de varios Estados americanos en el curso de algunos lustros. Así ha ocurrido en Argentina, que en 1994 elevó a rango constitucional un conjunto de instrumentos sobre derechos humanos, camino que más tarde siguió la República Dominicana; y en Colombia, Venezuela, Guatemala, Bolivia y Ecuador, que colocaron en el punto supremo de la escala normativa las disposiciones más favorables a los derechos de los individuos, independientemente de que provinieran del ordenamiento nacional o del internacional.

En seguida figura un "puente" legal, constituido por las normas de implementación destinadas a encauzar a nivel secundario el tránsito de las decisiones internacionales. No abundan las disposiciones de esta naturaleza. Las hay, por ejemplo, en Perú y en México; aquí sólo en lo que toca a responsabilidad patrimonial del Estado. A continuación mencionaré el "puente" jurisdiccional, concretado en la recepción de las disposiciones y los criterios jurisprudenciales internacionales por parte de los tribunales internos; en este ámbito opera el control de convencionalidad, entre otros extremos que sirven al mismo propósito.

Mencionemos, asimismo, el "puente" político, que se deposita en las políticas públicas elaboradas y aplicadas con perspectiva de derechos humanos, y el "puente" cultural, que reviste importancia decisiva para el conjunto de estas cuestiones, e implica el culto y el cultivo de la dignidad humana y del método jurídico para la prevención y la solución de los conflictos.

Hoy día es indudable la existencia de la doble fuente de los derechos humanos, a la que me referí en líneas anteriores, cuya presencia se desprende de los términos adoptados por la Constitución general de la República al establecer el novedoso puente del que ahora disponemos para la recepción interna del derecho internacional. Así se advertía desde la vigencia solitaria del artículo 133 de la Constitución general de la República (que se refiere a tratados internacionales 
como “Ley Suprema de la Unión”), norma que debió ser reformada en 2011 para que adquiriese mayor congruencia con los cambios constitucionales de este año. Y así se observa, con mayor énfasis y claridad, a partir de esta renovación en la ley suprema, que acoge el principio pro homine cuando dispone la aplicación -a través de una interpretación específicamente orientada- de la norma más favorable a la persona.

De esta suerte reaparecieron los derechos humanos en la escena constitucional, como lo habían estado en 1814, con la carta de Apatzingán, y en 1857, con la Constitución Federal de este último año. Y además ingresaron, en torrente, los derechos alojados en cualesquiera tratados internacionales (y declaraciones, como la Universal y la Americana) de los que México sea parte. Ésta es la fuente internacional de los derechos primordiales, provista por el orden jurídico de la materia y las otras ramas que colocan al ser humano en el centro de la escena, bajo la "garantía colectiva" y las obligaciones igualmente colectivas e individuales de los Estados.

El ingreso del derecho internacional de los derechos humanos obliga a replantear el conjunto del ordenamiento jurídico, en el que suelen descollar, para estos efectos, las dimensiones penal y procesal. Nos hallamos ante una dimensión supranacional del derecho concerniente a la justicia, como ha reconocido Mauro CapPELLETTl, invocado por Hitters. Martín ABREgú, en Argentina, invita a "volver a pensar el derecho procesal penal después de la irrupción de los tratados internacionales". El derecho internacional de la materia "tiene un fundamental papel para la reformulación del proceso penal a partir del nuevo paradigma de los derechos humanos". Julio MAIER señala que una "rama del derecho internacional debe ser especialmente considerada, no sólo debido a sus características particulares, sino, antes bien, a su influencia en el derecho procesal penal [...] derecho internacional de los derechos humanos".

Volvamos a la reforma constitucional de 2011 en México. Se ha creado, sin señalarlo explícitamente, un bloque de constitucionalidad en la medida en que las disposiciones del derecho internacional (de los derechos humanos) deben ser aplicadas cuando resulten más benéficas para el individuo, incluso a pesar de la estipulación diferente -que es una hipótesis infrecuente- contenida en el texto de la ley suprema. En fin, esas disposiciones poseerian rango constitucional (o supraconstitucional) y excluirían la aplicación de las previstas expresamente en la ley fundamental.

El tema del bloque de constitucionalidad -o bien, la cuestión de un bloque de convencionalidad superior- se actualiza, asimismo, cuando se observa que un tratado de derechos humanos que mejora la situación del sujeto prevalece sobre otro que no contiene o niega ese mismo rango de protección. Esto se 
SERGIO GARCÍA RAMÍREZ

infiere de la lectura conjunta de los artículos 101 y 105, reformado, atentos a la posibilidad de combatir con acción de inconstitucionalidad un tratado que se opone a otro más protector. Un argumento adicional en favor de esta consideración provendría del artículo 15 de la ley fundamental, en lo que toca a los principios de adquisición definitiva y progresividad, como los he designado, de los derechos humanos.

Todavía en el ámbito de la reforma al artículo $1^{\circ}$ constitucional de 2011, agreguemos que ésta obliga a todas las autoridades a respetar y garantizar los derechos humanos (como señala el artículo $1^{\circ}$ de la Convención Americana) que proceden de la doble fuente referida; que dispone reglas de interpretación favorables, pro homine ("protección más amplia"); que reconoce garantías nacionales e internacionales, cada una -entendemos- en su propio ámbito y con sus reglas y alcances característicos, y que alude a las reparaciones por violaciones (junto con otras obligaciones), "en los términos que establezca la ley".

Por cierto, es discutible e incluso objetable -y en todo caso promueve dudas y podría fundar interpretaciones encontradas- esta última expresión contenida al final del tercer párrafo del artículo $1^{\circ}$, si con ella se altera o reduce el amparo internacional invocando los términos que provea la ley interna. Tómese en cuenta que la jurisprudencia interamericana ha definido el gran alcance de las reparaciones, mucho más completo y dinámico que el correspondiente a las violaciones de derechos de fuente nacional.

Dos palabras sobre el contenido del derecho internacional de derechos humanos -ampliando la alusión que hice líneas arriba-, que no se reduce a la costumbre y la convención (tratados, protocolos). El juez interno -que ejerce el control de convencionalidad-y en general todas las autoridades domésticas -a las que se atribuyen obligaciones de prevención, respeto, garantía y reparacióndeben conocer el amplio contenido de ese derecho, para actuar en consecuencia. Ello no implica, por supuesto, que el juzgador doméstico deba aplicar directamente esas expresiones del derecho internacional; le servirán para establecer el alcance de los términos de una convención y, en consecuencia, fijar el marco del control de convencionalidad.

En el derecho internacional de los derechos humanos figuran, además de las fuentes mencionadas, otras de carácter diverso: así, declaraciones (por ejemplo, Universal y Americana, entre varias más de carácter específico), estatutos y reglamentos $(v . g r$., los correspondientes a la Comisión y a la Corte interamericanas), opiniones consultivas (de la Corte Interamericana), sentencias (idem), otras resoluciones jurisdiccionales (idem), recomendaciones (de la Comisión Interamericana, entre otras), informes (idem), principios, relatorías, conclusiones de encuentros internacionales, y así sucesivamente. 
Se acostumbra aludir a un derecho "duro", imperioso, inequívocamente vinculante para los Estados y, en general, para los sujetos a los que se extiende su ámbito subjetivo de aplicación, y de un derecho "suave" (soft law) que no posee el mismo carácter imperioso y vinculante. Existe una fuerte tendencia a dotar a este soft law de creciente eficacia. La Corte Interamericana ha subrayado el valor de las recomendaciones de la Comisión Interamericana a la luz del principio pacta sunt servanda.

En fin de cuentas, este gran conjunto de normas, disposiciones, requerimientos, aspiraciones, etcétera, integra el universo de los "estándares" internacionales, a los que se remite la actuación del Estado y la reclamación de los particulares; son el marco, el punto de referencia, la guía para unos y otros, constantemente invocados y discutidos. Bajo esta luz se mira o reconstruye el nuevo derecho, atento a los derechos humanos.

En seguida interesa precisar el valor que poseen las decisiones de la CorteidH, que es, por cierto, la instancia judicial internacional o supranacional a la que se ha vinculado el Estado mexicano en esta materia, con las consiguientes repercusiones sobre el ámbito de derechos y libertades de los habitantes de la República. En ese campo figuran las opiniones consultivas, las sentencias (en el curso o al cabo de procedimientos contenciosos), las medidas provisionales, las resoluciones sobre cumplimiento y otras determinaciones que emite el tribunal interamericano en el ejercicio de sus atribuciones jurisdiccionales.

Para resolver esta cuestión es pertinente recordar, como cuestión básica para el análisis, que la Convención Americana, seguida por otras normas -así, el Estatuto de la Corte-, ha confiado a ésta la atribución de interpretar y aplicar dicha Convención. Es el intérprete oficial del tratado americano. No se ha conferido semejante atribución a ninguna otra instancia, sin perjuicio de las facultades asignadas a la Comisión Interamericana, que no es un ente judicial.

La competencia material de conocimiento de la Corte Interamericana no se contrae solamente a la Convención Americana. También puede interpretar disposiciones sobre derechos humanos que figuren en otros tratados internacionales (en general, no únicamente americanos; en el mismo sentido se pronuncia, por lo que atañe a derechos de fuente internacional, el nuevo texto del artículo $1^{\circ}$ de la Constitución mexicana, posiblemente influido en este extremo por la CADH y la jurisprudencia de la CorteıDH), a condición de que éstos sean aplicables a países (alguno o algunos) de América. Esto se plantea en el ejercicio de la atribución consultiva, que ha ocurrido en varias oportunidades, inclusive a solicitud de México: opiniones consultivas oc-16, sobre derecho a información acerca de la asistencia consular a favor de extranjeros detenidos, y oc-18, en torno a derechos humanos de trabajadores migrantes indocumentados. 
La competencia contenciosa del tribunal que ahora examinamos tampoco se reduce a la $\mathrm{CADH}$. Otros instrumentos del ámbito americano le asignan competencia para conocer de cuestiones litigiosas. Éste es un punto largamente explorado por la jurisprudencia interamericana, maestra de su competencia (depositaria de la compétence de la compétence). De los términos claramente estatuidos por esos instrumentos y de la jurisprudencia interpretativa de la Corte se desprende que ésta puede aplicar directamente, además de la CADH, el Protocolo de San Salvador (en lo que respecta a los derechos de asociación laboral y de acceso a la educación: artículos 8.1.a y 13), la Convención para Prevenir y Sancionar la Tortura, la Convención contra la Desaparición Forzada de Personas y la Convención para Prevenir, Sancionar y Erradicar la Violencia contra la Mujer (Convención de Belém do Pará, cuya aplicabilidad he examinado detalladamente en mi voto particular al primer caso en el que la Corte asumió esta competencia: Penal Castro y Castro vs. Perú, del 25 de noviembre de 2006, a cuyas consideraciones me remito).

Hay un dato común a los tratados o convenios a los que nos hemos referido en los párrafos precedentes: todos ellos han ingresado en el ordenamiento nacional, merced al proceso de suscripción, ratificación y/o adhesión del Estado que los asume, como es el caso de México. Son, para nosotros, Ley Suprema de la Unión, como dice el artículo 133 constitucional; o bien, proveen derechos y libertades de los que gozan todos los individuos bajo la jurisdicción del Estado mexicano, como resuelve, desde 2011, el artículo $1^{\circ}$ de la Constitución general de la República. En suma, obligan al Estado y reconocen derechos (exigibles, por supuesto) a los individuos.

En mi voto sobre la sentencia del caso Trabajadores Cesados del Congreso vs. Perú señalé, en torno a este punto:

[...] al referirse a un "control de convencionalidad" [...] la Corte Interamericana ha tenido a la vista la aplicabilidad y aplicación de la Convención Americana sobre Derechos Humanos, Pacto de San José. Sin embargo, la misma función se despliega, por idénticas razones, en lo que toca a otros instrumentos de igual naturaleza, integrantes del corpus juris convencional de los derechos humanos de los que es parte el Estado: Protocolo de San Salvador, Convención para Prevenir y Sancionar la Tortura, Convención de Belém do Pará para la Erradicación de la Violencia contra la Mujer, Convención sobre Desaparición Forzada, etcétera. De lo que se trata es de que haya conformidad entre los actos internos y los compromisos internacionales contraídos por el Estado, que generan para éste determinados deberes y reconocen a los individuos ciertos derechos. 
Diré, además, que la Corte toma en cuenta, en el examen de asuntos litigiosos (esto es, en el despliegue de su competencia contenciosa), otros instrumentos del orden internacional, externos al sistema interamericano, que no le han conferido competencia material. En estos casos no adopta decisiones que impliquen la aplicación directa de tales convenios, a la manera en que lo hace con respecto a los instrumentos que le atribuyen esa facultad. Empero, recoge conceptos de aquéllos para fines de interpretación: establecimiento del contexto, conocimiento de estándares, inserción en el marco del derecho internacional contemporáneo. Así ha ocurrido en diversos casos en que la CorteidH invoca, por ejemplo, la Convención sobre los Derechos del Niño, la CEDaw, el Pacto Internacional de Derechos Civiles y Políticos, los Convenios de Ginebra, varios instrumentos referentes a derechos de migrantes, etcétera.

Finalmente, consideremos que en determinados extremos el tribunal interamericano analiza puntos que pudieran quedar abarcados en instrumentos que no le asignan competencia material, pero lo hace a través de la interpretación y aplicación de normas de la Convención Americana y en el ejercicio, por lo tanto, de potestades de las que se halla investida. Este es el caso, que menciono por vía de ejemplo, del derecho a la protección de la salud, analizable a partir del Protocolo de San Salvador -que no atribuye a la Corte competencia en este aspecto-, pero también analizable con base en el artículo $5^{\circ}$ de la CADH, que se refiere a la protección de la integridad personal.

Preguntémonos ahora cuál es el alcance de la eficacia vinculante de los actos de interpretación de la Corte Interamericana, tema que ha suscitado diversas opiniones y debates y que viene a cuentas, evidentemente, cuando se examina y ejerce el control interno de convencionalidad. En el estudio de esta cuestión podemos deslindar las funciones consultiva y contenciosa, y vincular a ésta -en un conjunto relativamente homogéneo- las funciones preventiva (medidas provisionales) y ejecutiva (supervisión de cumplimiento).

Regularmente se ha dicho que no son vinculantes para los Estados las opiniones de la Corte Interamericana emitidas en el desempeño de la función consultiva. Así lo ha considerado el propio tribunal. También se ha señalado que pudieran tener fuerza vinculante solamente para el Estado que solicitó la opinión y expresó, con ello, su voluntad de atenerse al parecer final del tribunal interamericano. Hay, desde luego, otros puntos de vista.

También se ha sostenido que las decisiones de la Corte en asuntos contenciosos son inmediatamente obligatorias, vinculantes, de forzosa observancia y cumplimiento para los Estados que aceptaron la competencia contenciosa e intervinieron en el proceso respectivo: esto es, poseen eficacia imperativa inter partes. Esta obligatoriedad no suscita dudas, en tanto se halla manifiestamente 
establecida en la Convención Americana y consta en los actos de aceptación de la competencia contenciosa de la Corte por parte de los Estados.

Varios altos tribunales del área americana han reconocido a la jurisprudencia de la Corteidn eficacia vinculante o fuerza orientadora, independientemente de que aquélla corresponda a casos que atañen directamente a los Estados en los que actúan esos tribunales o a terceros Estados sujetos a la Convención Americana. Puede verse una revisión de este punto, tan importante, en la sentencia de la CorteidH sobre el caso Cabrera García y Montiel Flores, del 26 de noviembre de 2010, en el que se invocan pronunciamientos muy interesantes de diversos órganos de la justicia interna: Sala Constitucional de la Corte Suprema de Costa Rica, Tribunal Constitucional de Bolivia, Suprema Corte de Justicia de República Dominicana, Tribunal Constitucional de Perú, Corte Suprema de Justicia de la Nación Argentina y Corte Constitucional de Colombia.

En mi opinión, los criterios establecidos por la Corte Interamericana al interpretar la $\mathrm{CADH}-\mathrm{y}$ otros instrumentos con respecto a los cuales dispone de competencia material-son vinculantes para los Estados partes en la Convención Americana, y con mayor razón para quienes son, además, sujetos de la jurisdicción contenciosa de la Corte. Sin embargo, esta sujeción no es indispensable para la eficacia vinculante de tales criterios con respecto a dichos Estados.

Sustento mi punto de vista en la consideración de que los Estados partes en la Convención Americana -y otras- han acogido este instrumento soberanamente, como parte de la preceptiva nacional, asumiendo los deberes que asigna y afrontando los derechos personales que reconoce. $Y$ esos mismos Estados han aceptado -también soberanamente, al constituirse en partes de la CADH- que la CorteidH, tribunal supranacional, es el órgano judicial llamado a interpretar las disposiciones convencionales. Por lo tanto, la interpretación de la Corte establece formal y oficialmente el alcance de tales disposiciones y, en consecuencia, la medida de los deberes de los Estados y los derechos de los particulares.

Así, no es posible sostener que las interpretaciones establecidas por la CorteIDH constituyan un punto de vista atendible o desatendible, y no un acto de necesaria observancia. Fijan -como se dice en Europa, no así en América- la "cosa interpretada"; implican, como prefiero decir, una interpretación vinculante de textos normativos asimismo vinculantes para los Estados, que deben ser entendidos y aplicados interiormente en los términos de la interpretación formal y final dispuesta por la Convención y ejercida por la Corte.

Reconozco esa eficacia tanto a las opiniones consultivas como a las sentencias en casos contenciosos $-\mathrm{y}$ a las resoluciones sobre medidas provisionales y cumplimiento de sentencias- en cuanto tiene que ver con interpretación de normas. Otro tanto se puede decir, aunque acepto que el punto es más complejo y 
requiere cuidadoso análisis, en lo que toca a disposiciones de tratados diferentes que la Corte examina por la vía consultiva.

Por supuesto, al hablar de esta eficacia erga omnes y no sólo inter partes, sólo me estoy refiriendo, como es obvio, a la interpretación de normas, la fijación del sentido de las disposiciones convencionales, el entendimiento general del precepto para todos los fines aplicativos que éste pueda tener, no así a los extremos específicos del caso en el que se hizo la interpretación: hechos y condenas puntuales, que sólo conciernen al Estado y a la víctima que comparecieron en el juicio, y con respecto a los cuales es indudable la fuerza inter partes de la sentencia emitida por el tribunal.

En esta misma línea de consideraciones, corresponde aclarar -como se ha hecho en otro lugar de este trabajo- que las interpretaciones del tribunal interamericano pueden verse superadas por actos -instrumentos internacionales, disposiciones nacionales, actos de la jurisdicción interna- que reconozcan a los individuos mayores o mejores derechos y libertades. El derecho internacional de los derechos humanos es el "piso" de los derechos, no el "techo". Esta conclusión, que deriva inmediatamente del principio pro homine, tiene soporte en las normas de interpretación contenidas en el artículo 29 de la Convención Americana.

¿Pueden los tribunales internos, en el desempeño del control de convencionalidad, formular interpretaciones propias acerca de normas de derecho internacional, cuando venga al caso la aplicación de éstas a los casos de los que estén conociendo? La respuesta es afirmativa, enfáticamente, cuando no exista jurisprudencia de la Corte Interamericana sobre la norma que los juzgadores nacionales examinan y pretenden aplicar. En tales supuestos, si no se llevase adelante una interpretación doméstica, la norma internacional quedaría inaplicada, con todo lo que ello apareja.

Lo que resultaría impertinente es que el control interno de convencionalidad entrara en colisión con el control supranacional de convencionalidad (salvo en los casos, ya señalados, en que aquélla mejore los términos de ésta) o actuara al garete de los principios y objetivos del control de convencionalidad a los que me referí en la primera parte de este artículo.

\section{La responsabilidad unitaria del Estado}

En el estudio del control interno de convencionalidad viene a cuentas la responsabilidad internacional del Estado, en tanto se trata de establecer no solamente si el juzgador doméstico puede ejercer dicho control, sino si debe ejercerlo. A este deber sujeto a examen se añaden otras manifestaciones de una obligación 
judicial: ante todo, el ejercicio oficioso del control (que además actualiza, en esta vertiente, la operación del principio jura novit curia) y, por supuesto, las consecuencias jurídicas del incumplimiento, así como los límites del control a los que antes me referi y sobre los que volveré adelante, en alguna medida.

En la escena internacional, el Estado actúa unitariamente; no comparecen aisladamente, como sujetos plenos e inconexos, algunos órganos o agentes de aquél. Me estoy refiriendo, es evidente, a la comparecencia que se traduce en asunción deliberada de deberes generales y a la aplicación estricta de las obligaciones asumidas. En consecuencia, aquéllos abarcan al Estado en su conjunto, repercuten sobre él, le son exigibles, sin perjuicio de la distribución interna de atribuciones y funciones, que depende de la voluntad particular de los Estados y no altera los deberes y las consecuencias internacionales.

Esto se proyecta con relevancia hacia un doble plano de la organización político-jurídica del Estado: en una dimensión, los poderes tradicionales y los nuevos órganos autónomos, que en México han surgido con vigor durante las últimas décadas (además de las figuras de autonomía institucional consagradas de tiempo atrás, como ocurre en el caso de las universidades públicas); y en otra, hacia los planos, niveles o ámbitos del Estado, el gobierno o la administración, donde a su vez existe distribución de funciones y tareas en diversos poderes y órganos.

Esto interesa para fijar la responsabilidad internacional del Estado en contiendas ventiladas ante instancias de ese carácter. En el voto que emití con respecto a la sentencia dictada por la Corte Interamericana en el caso Myrna Mack Chang vs. Guatemala, del 25 de noviembre de 2003, analicé esta materia:

Para los efectos de la Convención Americana y del ejercicio de la jurisdicción contenciosa de la Corte Interamericana, el Estado viene a cuentas en forma integral, como un todo. En este orden, la responsabilidad es global, atañe al Estado en su conjunto y no puede quedar sujeta a la división de atribuciones que señale el derecho interno. No es posible seccionar internacionalmente al Estado, obligar ante la Corte sólo a uno o algunos de sus órganos, entregar a éstos la representación del Estado en el juicio -sin que esa representación repercuta sobre el Estado en su conjunto-y sustraer a otros de este régimen convencional de responsabilidad, dejando sus actuaciones fuera del "control de convencionalidad" que trae consigo la jurisdicción de la Corte internacional.

En tal virtud, los órganos jurisdiccionales, que son integrantes del Estado, se hallan igualmente comprometidos por el derecho internacional de los derechos humanos, de donde resulta un cimiento del control interno de convencionalidad, 
conclusión que ciertamente no riñe con la posibilidad, conveniencia y necesidad de que ese control se ejerza en forma ordenada y armoniosa, para el mejor servicio a los fines que pretende alcanzar. Desde luego, esta conclusión se extiende tanto a las jurisdicciones del Estado federal, en su caso, como a las de los estados federados o provincias, en el suyo. Ni aquél ni éstos podrían alterar la responsabilidad que les incumbe y las consecuencias que derivan de ella, aduciendo la estructura federal.

Recordemos el artículo 29 de la Convención de Viena sobre el Derecho de los Tratados: "Un tratado será obligatorio para cada una de las partes por lo que respecta a la totalidad de su territorio, salvo que una intención diferente se desprenda de él o conste de otro modo". La inoponibilidad de la estructura federal al cumplimiento de los deberes del Estado, necesariamente globales o integrales, se ha examinado en la jurisprudencia de la CorteidH; son ejemplos las sentencias de fondo (1996) y reparaciones (1998) del caso Garrido y Baigorria vs. Argentina. He aquí otra referencia útil para la admisión del control interno de convencionalidad, que tampoco resta fuerza al requerimiento de que ese control opera en forma ordenada y armoniosa.

En mi voto agregado a la sentencia del caso Trabajadores Cesados del Congreso vs. Perú, señalé a propósito del control interno que si

[...] los instrumentos internacionales son inmediatamente aplicables en el ámbito interno, los tribunales nacionales pueden y deben llevar a cabo su propio "control de convencionalidad". Así lo han hecho diversos órganos de la justicia interna, despejando el horizonte que se hallaba ensombrecido, inaugurando una nueva etapa de mejor protección de los seres humanos y acreditando la idea -que he reiterado- de que la gran batalla por los derechos humanos se ganará en el ámbito interno, del que es coadyuvante o complemento, pero no sustituto, el internacional.

En este mismo ámbito conviene advertir -como antes manifesté- que el control de convencionalidad debiera ejercerse de manera inmediata, espontánea, es decir, oficiosa. Esto mismo acontece con el respeto y la garantía de los derechos humanos al que están obligadas todas las autoridades. Sería absurdo aguardar a que el interesado invoque sus derechos - a la vida, a la integridad, a la libertadpara que los agentes del Estado se resuelvan a examinar la existencia de aquéllos, la obligación de respetarlos y la necesidad de garantizar su ejercicio. Otro tanto diremos de los órganos jurisdiccionales.

En la actuación de estos órganos es necesario traer a colación el antiguo principio de la actividad judicial -que frecuentemente acoge la jurisprudencia interamericana- en el sentido de que jura novit curia: el juzgador conoce el 
derecho; no es indispensable que lo invoquen los litigantes (aunque harán bien en invocarlo, lo aconseja la experiencia). Lo conoce, pues, y debe aplicarlo.

De ahí la regla de oficiosidad en el control interno de convencionalidad, como hay oficiosidad en el control externo, original o propio: la Corte Interamericana, que no actúa como mecanismo de investigación y por ello se atiene a los hechos invocados por la Comisión, aplica directamente las normas convencionales cuando el expediente muestra la existencia de un supuesto de hecho que reclama esa aplicación, aunque la Comisión Interamericana no lo haya requerido. También ha procedido a esa aplicación a solicitud de la víctima y sus representantes, que no pueden añadir hechos al tema fáctico propuesto por la Comisión en la demanda (hoy día, en el informe con el que insta la intervención jurisdiccional).

\section{Imputación al Estado}

El tribunal interno que ejerce el control de convencionalidad no podría ignorar las reglas sobre imputación al Estado de responsabilidad generada por la conducta de diferentes sujetos. Obviamente, el Estado - una abstracción, que se concreta dolorosamente en la especie de las violaciones a derechos humanos- no actúa por sí mismo, que no podría, sino a través de órganos o personas cuya conducta - activa u omisiva, según el régimen aplicable- determina la responsabilidad internacional del Estado. La CorteidH explora esa imputación, su pertinencia y su alcance; otro tanto debe hacer el juez interno, para sus propios efectos, en el marco del control de convencionalidad.

Las reglas de imputación al Estado, de la que depende la pertinencia de una declaratoria de violación de derechos y libertades y una condena a sufrir ciertas consecuencias jurídicas (reparaciones), que favorecerán a la víctima (y a otras personas), se elevan sobre disposiciones estatutarias y resoluciones jurisprudenciales. No pretendo ir muy lejos en el examen de este punto -que ya no será extraño para los tribunales domésticos-, pero debo observar que la jurisprudencia interamericana se ha desplegado ampliamente sobre él, hasta definir una doctrina pacíficamente aceptada, que se encuentra en vigor.

Es imputable al Estado la conducta de sus agentes u órganos formales, por acción u omisión, extremos separados por una frontera que en ocasiones resulta ambigua, elusiva, sobre todo cuando se aduce la figura de omisión. Tómese en cuenta el concepto de "Estado-garante", que deriva de los artículos $1^{\circ}$ y $2^{\circ} \mathrm{CADH}$ : garante general de los derechos de las personas bajo su jurisdicción, concepto

que implica posibilidad de regulación o actuación eficaz, no necesariamente territorialidad (en este ámbito es interesante la decisión de la CorteıDH en el 
caso Goiburú y otros vs. Paraguay, del 22 de septiembre de 2006, que abarcó autoridades persecutorias en varios Estados del Cono Sur del continente), y garante especial: mayor acento en la misión garantizadora del Estado cuando la vida cotidiana del individuo se halla sujeta al control inmediato de la autoridad, como acontece en el supuesto de sujetos privados de libertad (en "instituciones totales").

También se imputa responsabilidad al Estado en el supuesto de delegación o subrogación de atenciones que regularmente brinda aquél en forma directa, según se resolvió en la importante sentencia del caso Ximenes Lopes vs. Brasil, del 4 de julio de 2006. También aparece la responsabilidad internacional del Estado, a partir de conductas de particulares, en situaciones de conflicto interno de corte tradicional y en supuestos de grave inseguridad y riesgo.

Con respecto a aquellas situaciones y a sus actores particulares - pero que actúan con la participación, protección, tolerancia o indiferencia del Estado- la Corte recordó en la sentencia del caso Masacre de Mapiripán vs. Colombia, del 15 de septiembre de 2005 -resolución que acoge una constante línea jurisprudencial-, que:

[...] las obligaciones del Estado proyectan sus efectos más allá de la relación entre sus agentes y las personas sometidas a su jurisdicción, pues se manifiestan también en la obligación positiva del Estado de adoptar las medidas necesarias para asegurar la efectiva protección de los derechos humanos en las relaciones inter-individuales. La atribución de responsabilidad al Estado por actos de particulares puede darse en casos en que el Estado incumple, por acción u omisión de sus agentes cuando se encuentren en posición de garantes, esas obligaciones erga omnes contenidas en los artículos 1.1 y 2 de la Convención.

La Corte se ha referido al supuesto en que los hechos sean obra de terceros, pero el Estado haya incurrido en falta de la debida diligencia para prevenir la violación o para tratarla en los términos requeridos por la Convención. Hay ejemplos numerosos en la experiencia de la CorteidH: casos de Guatemala por intervención de las llamadas "patrullas civiles"; casos de Colombia por actuación de grupos paramilitares ("autodefensas") en masacres, y algún caso de Brasil en lo que respecta a prisiones: delitos cometidos en el interior o a partir del interior hacia el exterior de la cárcel.

En la sentencia correspondiente al caso de la Masacre de Pueblo Bello vs. Colombia, del 31 de enero de 2006, se examinó el alcance de la responsabilidad estatal tomando en cuenta las condiciones en que ocurrieron los hechos; se requiere que el riesgo sea previsible y evitable. A este respecto, el voto particular 
del juez García Sayán señaló: “conocimiento de una situación de riesgo real e inmediato", proyectada sobre "un individuo o grupo de individuos determinado", y existencia de "posibilidades razonables de prevenir o evitar ese riesgo".

También es muy importante la elaboración jurisprudencial interamericana en el notorio caso González y otras (Campo Algodonero) vs. México, del 16 de noviembre de 2009: "los Estados deben adoptar medidas integrales para cumplir con la debida diligencia en casos de violencia contra las mujeres". En tales condiciones se requiere: marco jurídico de protección, aplicación efectiva del mismo y políticas de prevención, así como prácticas que permitan actuar eficazmente ante denuncias. Igualmente, "medidas preventivas en casos específicos en los que es evidente que determinadas mujeres y niños pueden ser víctimas de violencia”.

\section{El control de convencionalidad en la doctrina jurisprudencial de la CorteiDH}

La aparición y el desarrollo de esta doctrina han sido examinados por tratadistas mexicanos y extranjeros. Ya mencioné varios en la Advertencia que figura en el inicio de este trabajo. Además de los ya citados, también se ha ocupado del tema Gumesindo García Morelos, entre los profesores mexicanos. Últimamente lo ha hecho, desde la perspectiva del derecho constitucional, José María SERNA DE LA GARZA. Un valioso conjunto de trabajos de muy provechosa consulta en torno a esta cuestión es la obra colectiva coordinada por Susana AlBANESE, bajo el título El control de convencionalidad (Argentina, 2008). El tratamiento doctrinal de la materia avanza con diligencia.

La primera vez que se aludió al control de convencionalidad en el marco de la Corte Interamericana, destacando la función de ésta en ese campo, fue en mi voto sobre el citado caso Mack Chang vs. Guatemala, del 25 noviembre de 2003. Posteriormente volví a examinar este asunto en el voto relativo al caso Tibi, también citado antes, del 7 de septiembre de 2004. Hice ahí la comparación entre la CorteIDH y los tribunales constitucionales: control de convencionalidad y control de constitucionalidad, en sus respectivos casos. El cotejo es útil en muchos extremos, entre ellos para fijar la trascendencia $-\mathrm{y}$ la extraordinaria delicadeza- de los pronunciamientos de estos órganos con respecto al conjunto del orden jurídico y las decisiones judiciales que se pronuncian a su amparo.

Nuevamente me ocupé del tema en el voto emitido acerca de los casos Trabajadores Cesados del Congreso vs. Perú (Aguado Alfaro y otros), del 24 de noviembre de 2006, y Vargas Areco vs. Paraguay, del 26 de septiembre de los 
mismos mes y año. En esta última fecha -la coincidencia no es casual- la Corte Interamericana asumió la doctrina del control de convencionalidad en el conocido caso Almonacid Arellano vs. Chile, que amplió y difundió, con efectos muy apreciables, el conocimiento de esta materia en las jurisdicciones nacionales. Reanudé mi examen del control de convencionalidad en mi voto sobre el caso Valle Jaramillo, del 27 de noviembre de 2008.

En la sentencia de Almonacid, el tribunal postuló: tomando en cuenta que el Estado se halla obligado, en su conjunto, por el tratado internacional de protección de los derechos humanos,

[...] el Poder Judicial debe ejercer una especie de 'control de convencionalidad' entre las normas jurídicas internas que aplican en los casos concretos y la Convención Americana sobre Derechos Humanos. En esta tarea, el Poder Judicial debe tener en cuenta no solamente el tratado, sino también la interpretación que del mismo ha hecho la Corte Interamericana, intérprete última de la Convención Americana.

En la sentencia de Trabajadores Cesados del Congreso, la CorteidH puntualizó acertadamente su criterio con algunos elementos relevantes que informarian posteriores sentencias del tribunal interamericano. Así, manifestó que el control debe ejercerse ex officio, es decir, motu proprio por los juzgadores, como expresión del deber estatal que comparten éstos. $Y$ añadió con razón que los tribunales internos deben despachar el control "evidentemente en el marco de sus respectivas competencias y de las regulaciones procesales correspondientes".

Otro agregado importante hecho por la Corte indica: la aplicación del control de convencionalidad "no puede quedar limitada exclusivamente por las manifestaciones o actos de los accionantes en cada caso concreto, aunque tampoco implica que ese control deba ejercerse siempre, sin considerar otros presupuestos formales y materiales de admisibilidad y procedencia de ese tipo de acciones". Es así que el tribunal interamericano advierte sobre la existencia y eficacia de presupuestos formales internos de admisibilidad y procedencia (como los hay, por cierto, en el ámbito internacional y para los efectos de la apertura y desarrollo de la vía correspondiente, sea ante la Comisión Interamericana, sea ante la Corte).

Posteriormente, la Corte ha dictado varias sentencias sobre la misma materia y en el mismo sentido. Entre ellas figuran, de fechas muy recientes y con la mayor importancia por su proyección inmediata en nuestro país, varias atinentes a hechos que ocurrieron en México y con respecto a los cuales la jurisdicción interamericana dictó sendas condenas. Las mencioné anteriormente: casos González y otras (Campo Algodonero), Radilla Pacheco, Fernández Ortega y otros, Rosendo Cantú y otra, y Cabrera Garcia y Montiel Flores. 
SERGIO GARCÍA RAMÍREZ

\section{Control interno de convencionalidad y obligaciones generales de los Estados (artículos $1^{\circ}$ y $2^{\circ} \mathrm{CADH}$ )}

Habida cuenta de la vinculación de los Estados a la CADH, en tanto partes del Convenio, y en seguida a la competencia contenciosa de la Corte (relación, esta última, que no es indispensable para los fines del control que estamos analizando), es preciso destacar los deberes a cargo de los Estados en función de aquel instrumento -otros, de orden internacional, recogen obligaciones del mismo carácter-que se deducen de los artículos $1^{\circ}$ y $2^{\circ} \mathrm{CADH}$ : en primer término, respeto y garantía, ya mencionados; en segundo, como manifestación de éstos, deber de adoptar medidas de múltiple naturaleza para asegurar ese respeto y proveer esa garantía.

La obligación de garantía - “escudo y espada” de la de respeto- significa, desde la resolución del señero caso Velásquez Rodríguez vs. Honduras, del 29 de julio de 1988, "el deber de los Estados parte de organizar todo el aparato gubernamental y, en general, todas las estructuras a través de las cuales se manifiesta el ejercicio del poder público, de manera que sean capaces de asegurar jurídicamente el libre y pleno ejercicio de los derechos humanos". Es obvio, glosemos, que en los órganos jurisdiccionales se manifiesta el ejercicio del poder público para asegurar el libre y pleno ejercicio de los derechos humanos.

Esta obligación de garantía puede suponer la operación del artículo $2^{\circ}$, que es, en rigor, un "rostro" del precepto anterior, y se proyecta en medidas de amplio espectro: del Estado hacia sí mismo: orden jurídico y estructura, atribuciones y prácticas; y del Estado hacia la sociedad: impulso a cambios que modifiquen las condiciones estructurales de las violaciones. Ejemplos de esto último es la conducta señalada al Estado en la sentencia del caso Servellón García vs. Honduras, del 21 de septiembre de 2006, para combatir la estigmatización social de ciertos grupos de menores de edad, y la acción a propósito de los patrones culturales, que se ordena en la sentencia del caso Campo Algodonero vs. México, en tanto esos patrones propician agresión contra las mujeres.

En la sentencia correspondiente al caso Cesti Hurtado vs. Perú, del 29 de septiembre de 1999, el tribunal interamericano hizo ver que los Estados no pueden "dejar de tomar las medidas legislativas 'o de otro carácter que fueren necesarias para hacer efectivos tales derechos y libertades', en los términos del artículo $2^{\circ}$ de la Convención. Estas medidas son las necesarias para garantizar [el] libre y pleno ejercicio de dichos derechos y libertades, en los términos del artículo 1.1 de la misma". 
En la sentencia del caso Yatama vs. Nicaragua, del 23 de junio de 2005, la CorteidH mencionó que:

[...] el deber general del Estado de adecuar su derecho interno a las disposiciones de [la $\mathrm{CADH}]$ para garantizar los derechos en ella consagrados, establecido en el artículo 2, incluye la expedición de normas y el desarrollo de prácticas conducentes a la observancia efectiva de los derechos y libertades consagrados en la misma, así como la adopción de medidas para suprimir las normas y prácticas de cualquier naturaleza que entrañen una violación a las garantías previstas en la Convención. Este deber general del Estado parte implica que las medidas de derecho interno han de ser efectivas (principio del effet utile), para lo cual el Estado debe adaptar su actuación a la normativa de protección de la Convención.

Los tribunales son órganos del Estado, cuyas sentencias constituyen, sin duda, medidas contribuyentes - o no- a garantizar el respeto a los derechos humanos previstos en la CADH. De ahí resulta un argumento más a favor del control de convencionalidad, sin que el ejercicio de esta facultad -y deber- de los tribunales implique menoscabo para la adopción de disposiciones competenciales y procedimientos judiciales idóneos - lo ha señalado la propia jurisprudencia de la CorteıDH- para alcanzar el gran objetivo perseguido por el régimen tutelar continental y por los instrumentos de los que éste se vale, entre ellos las sentencias nacionales.

\section{Control interno de convencionalidad derivado del carácter subsidiario de la jurisdicción internacional y de la "vocación" institucional de la CorteidH}

La jurisdicción interamericana no pretende y jamás se propuso sustituir a las jurisdicciones nacionales en el oficio protector de los derechos humanos. Esto consta en los trabajos preparatorios de la Convención, entre ellos las deliberaciones en la Conferencia de 1969, celebrada en San José, y en la posición expresamente adoptada al término de ella por la delegación mexicana, que figura en el Acta Final del encuentro. Esa jurisdicción a cargo de la CorteidH tiene carácter subsidiario o complementario. Tal es su naturaleza, de la que no se ha apartado ni podría hacerlo, jurídica y prácticamente.

Por ende, la justicia supranacional interviene en supuestos bien acotados: cuando la jurisdicción interna no opera o no resuelve debidamente la violación cometida; se solicita, a partir de aquella condición y una vez agotados los recur- 
sos internos para combatir el desvío o la inactividad del Estado, la apertura de la vía internacional ante la Comisión Interamericana y ésta resuelve de manera favorable - por acuerdo de admisibilidad- la solicitud del interesado, y finalmente la propia Comisión lleva el litigio al conocimiento de la Corte.

El tribunal de San José ha deslindado dos momentos o situaciones con respecto a la responsabilidad del Estado reclamable ante los tribunales. El primer momento corresponde a la aparición de la responsabilidad internacional del Estado, que se plantea cuando éste incurre en un hecho internacionalmente ilícito (violación de la CADH y otros tratados del ámbito americano, a los que me he referido). El segundo momento corresponde a la actualización de la competencia de la CorteiDH para conocer de esa violación y resolver mediante sentencia, que proviene de un dato diferente y posterior al momento que enuncié en primer término: la inexistencia o inoperancia del recurso interno para la debida solución del agravio.

En fin de cuentas, todo el sistema jurisdiccional internacional está montado sobre la idea de dar al Estado la oportunidad de resolver internamente el litigio, a través de los medios domésticos conducentes a ese fin. Uno de ellos es la actividad jurisdiccional. Ésta no puede perder de vista el carácter ilícito del hecho aducido, desde la perspectiva internacional, además de la calificación que le corresponda desde la nacional. De ahí se sigue que la jurisdicción doméstica debe salir al paso de la ilicitud internacional y aplicar las normas que establecen la existencia de ésta, sus características y consecuencias. De nueva cuenta nos encontramos con un fundamento para la operación -ordenada y armoniosadel control interno de convencionalidad.

En este campo de consideraciones, conviene tener en cuenta que la aplicación del derecho internacional de los derechos humanos omitida por la jurisdicción interna, que desdeña la oportunidad para asumirla, será la practicada por la jurisdicción internacional, que actuará subsidiariamente, en su propia oportunidad, para aplicar las disposiciones jurídicas internacionales quebrantadas o desatendidas. Existe, pues, ocasión para resolver en la vía interna lo que finalmente se traslada a la justicia internacional.

Bajo esta óptica conviene juzgar y entender el flujo de "casos mexicanos" a la Corte Interamericana, que ha sido inusualmente intenso: seis litigios en poco más de tres años. No sobra mencionar que en ese conjunto figuran hechos y conceptos de violación reiterados. La situación es comparable -en términos de frecuencia de litigios - a la que se presentó hace algunos años en relación con Perú, donde prevalecían condiciones de manifiesto autoritarismo, situación diferente de la que se plantea en el caso de México. 


\section{Control interno de convencionalidad y debido proceso. El juez natural}

El control judicial interno de convencionalidad supone el acceso a la justicia a través del debido proceso, concepto fundamental de los sistemas nacional e internacional de protección de los derechos humanos. El juzgador es la pieza central del acceso a la justicia y el despacho de ésta a través del debido proceso. Las características y el papel de éste frente al individuo que reclama su derecho -0 pretende reclamarlo- se hallan en el artículo $8^{\circ} \mathrm{CADH}$.

En consecuencia de lo anterior, es preciso examinar el órgano investido de atribuciones jurisdiccionales, sea un ente formalmente judicial, sea uno de diverso carácter o denominación, pero dotado de atribuciones materialmente jurisdiccionales. Esto reviste interés específico en lo que respecta al eventual control por parte de órganos jurisdiccionales que actúan en su propio ámbito de competencia previsto por la normativa doméstica.

Aquí queda a la vista el doble papel del juzgador: por una parte, es el órgano que resuelve una controversia y decide sobre derechos y obligaciones de los contendientes; por la otra, es garante de los derechos humanos: protector de éstos en cuanto a las personas que participan -o lo pretenden- en el enjuiciamiento.

El debido proceso es un concepto dinámico, expansivo, que se proyecta sobre el control judicial de convencionalidad, como sobre cualquier contienda en la que interviene un órgano del Estado para conocer cargos penales o resolver derechos y deberes en otras materias, conforme al artículo 8.1 CADH. Ese órgano debe satisfacer las condiciones del juez natural al amparo de esa misma norma. De él se reclaman, por lo tanto, independencia, imparcialidad y competencia.

El juez natural - ha dicho la CorteidH- es un presupuesto del debido proceso, no sólo un elemento. En su ausencia, no existe verdadero proceso: decae el conjunto de formas practicadas -enjuiciamiento aparente- y carece de validez la supuesta sentencia, instalada en ese precario cimiento.

El punto se ha planteado a propósito de la jurisdicción militar, tema frecuentemente explorado por la CorteidH y últimamente suscitado en casos concernientes a México. Un juez incompetente (militar) no puede ejercer, válidamente, el control de convencionalidad, salvo para declinar su competencia. El juez competente (ordinario) debería desechar inmediatamente la competencia del militar y, en general, de las autoridades de este fuero para investigar y juzgar. Volveré sobre este punto al informar acerca de la posición de la Suprema Corte de Justicia con respecto a los deberes derivados de la sentencia interamericana en el caso Radilla Pacheco. 
Un paso en falso de la jurisdicción interna en el terreno del debido proceso - precisamente a propósito de la figura del juez natural- comprometería o desacreditaría el control interno de convencionalidad: más aún, incrementaría los puntos cuestionables ante la justicia supranacional; primero, la confrontación entre el acto combatido y la norma internacional, y luego la inoperancia del juzgador que se avino a ejercer, de oficio, un control de convencionalidad, cuyo primer tema es la incompetencia de quien preside la investigación y el proceso.

\section{Métodos para el control: concentrado y difuso}

Esta cuestión ha sido ampliamente abordada a propósito de la jurisdicción constitucional y representa uno de los temas clásicos del derecho procesal constitucional. Es aquí -no en el derecho internacional y su aplicación interna- donde tuvo desarrollo inicial, que ahora se ha proyectado al ámbito que examino en este artículo.

En esencia, existen dos posibilidades - con variantes o modalidades que no analizaré en este momento- para el ejercicio del control jurisdiccional de constitucionalidad de leyes: concentrado, que deposita ese control en un órgano jurisdiccional supremo (que no formaría parte del aparato judicial tradicional, sino desempeñaría su elevada misión por encima de los órganos clásicos de la división de poderes), y difuso, que asigna el control a un amplio número de juzgadores, acaso a todos los titulares de la función jurisdiccional, llamados a pronunciarse sobre la constitucionalidad de las normas internas que, en principio, deben aplicar, y autorizados para "desaplicar" o invalidar, eventualmente, esas disposiciones cuando las consideran incompatibles con la ley fundamental a la que debieran ajustarse.

Estas formas de control, diseñadas para conducir la relación entre normas domésticas de diversa jerarquía, pueden trasladarse al ámbito de la relación entre norma internacional y norma interna. La existencia de una Corte Interamericana designada como intérprete de la Convención Americana y otros instrumentos, en los términos que ya expliqué, implica una expresión de control concentrado. Empero, ésta no es absoluta, porque la propia Corte ha reconocido a los tribunales nacionales -en la forma y términos que anteriormente recordé- la posibilidad de aplicar las normas internacionales sobre derechos humanos para dar cumplimiento, en su ámbito de atribuciones, a los deberes internacionales del Estado contenidos en los artículos $1^{\circ}$ y $2^{\circ}$ del Pacto de San José.

Cuando aludí a esta cuestión como integrante de la Corte Interamericana, señalé -así, en el multicitado voto correspondiente al caso Trabajadores $\mathrm{Ce}$ - 
sados del Congreso vs. Perú- que el control de convencionalidad, "de cuyos buenos resultados depende la mayor difusión del régimen de garantías, puede tener -como ha sucedido en algunos países- carácter difuso, es decir, quedar en manos de todos los tribunales cuando éstos deban resolver asuntos en los que resulten aplicables las estipulaciones de los tratados internacionales de derechos humanos".

La adopción del sistema de control difuso, añadí en el mismo voto,

[...] permitiría trazar un sistema de control extenso -vertical y general- en materia de juridicidad de los actos de autoridades - por lo que toca a la conformidad de éstos con las normas internacionales sobre derechos humanos-, sin perjuicio de que la fuente de interpretación de las disposiciones internacionales de esta materia se halle donde los Estados la han depositado al instituir el régimen de protección que consta en la CADH y en otros instrumentos del corpus juris regional. Me parece que ese control extenso -al que corresponde el "control de convencionalidad"- se halla entre las más relevantes tareas para el futuro inmediato del Sistema Interamericano de Protección de los Derechos Humanos.

Sin perjuicio de la preferencia por uno u otro régimen de control, lo cierto es que la Corte Interamericana no se ha pronunciado por ninguno de ellos con preferencia sobre el otro. Lo importante es que haya control de convencionalidad. Resulta secundario y opinable $-\mathrm{y}$ en todo caso depende de las circunstancias nacionales- el método que se elija, mientras no excluya el cumplimiento del deber de control que atañe a los depositarios de la función jurisdiccional pública.

Nos hallamos, pues, ante una decisión de método que compete a los Estados, soberanamente, y que éstos debieran adoptar previo cuidadoso examen de sus condiciones específicas y de la forma que mejor se acomode a la obtención de los fines perseguidos mediante la figura del control. Otro tanto se podría decir, mutatis mutandis, con respecto al control de constitucionalidad, tema que no me corresponde examinar ahora.

Fundo mi parecer en las reiteradas -constantes, enfáticas y ciertamente deliberadas- expresiones de la Corte Interamericana a propósito del control de convencionalidad conforme a la competencia de los órganos jurisdiccionales internos y bajo los procedimientos establecidos para este efecto, expresiones que antes cité literalmente. La alusión a competencias (al amparo del principio de legalidad, corresponde a la ley la asignación de competencia a los órganos judiciales) y a procedimientos (cuyo diseño y alcance incumben igualmente a la ley) no apareja por fuerza que todos los jueces sean competentes para aplicar, sin mayores exigencias internas, el control de convencionalidad. Es perfectamente 
posible, en mi concepto, que el ordenamiento interno establezca competencias específicas (que pudieran recogerse en "grados" de competencia) para el despacho del control y la fuerza de las decisiones judiciales domésticas a este respecto.

Se han expresado diversas opiniones en torno a la materia que ahora menciono, tanto en general como en lo que respecta a México. Algunos estimables tratadistas, como FERRER MAC-GREgor -en su voto para el caso Cabrera García y Montiel Flores (2010) - y GARCía Morelos, se inclinan hacia el régimen de control difuso. El primero de los mencionados examina ciertos rangos de "intensidad" en las facultades de control reconocidas a los juzgadores, que pudieran llegar a la inaplicación de normas inconvencionales, al planteamiento de una "duda de convencionalidad" ante órganos jurisdiccionales facultados para atenderla o, en el extremo, a "declarar su invalidez, según la competencia que la Constitución y leyes nacionales otorguen a cada juzgador, lo que provocará un grado de intensidad mayor del control de convencionalidad".

En mi opinión, es preferible organizar el control de convencionalidad a través de consultas sobre las disposiciones que se pretende aplicar, sobre todo en un medio donde hay "costumbre de control concentrado" y escaso manejo del derecho internacional, además de "vientos de fronda" que pudieran agitar las aguas de la jurisprudencia.

Estas consultas operarían de manera similar a las llamadas cuestiones de inconstitucionalidad, previstas en otros ordenamientos - de cuyo examen se ha ocupado, entre nosotros, el investigador Edgar CoRzo-, que implican elevar a un órgano superior de interpretación el planteamiento acerca de la convencionalidad o inconvencionalidad de una norma, y seguir el pronunciamiento que emita ese órgano. Ojalá que éste fuese el más alto tribunal, para asegurar la armonía de la jurisprudencia y su adecuada inscripción en el jus commune que se aspira a construir.

En sentido similar debo mencionar la posibilidad que apunta FerRer MacGREGor en una parte del texto antes transcrito, y desde luego los pareceres de SAGüÉs, expuestos en su artículo "El control de convencionalidad como instrumento para la elaboración de un ius commune interamericano", y SERNA DE LA GARZA -en el artículo que mencioné supra-, quien observa, con toda razón, que la formulación del control de convencionalidad por parte de la Corte Interamericana "ha dejado un margen para que los Estados decidan sobre el tipo de control que más les convenga".

Establecido que el control se ejerce en el marco de ciertas competencias -que deberán quedar fijadas al amparo del principio de legalidad-y conforme a determinados procedimientos - que se hallarán previstos bajo ese mismo principio-, hay que recodar las otras expresiones de la Corte Interamericana en este 
campo. Si son determinantes los conceptos jurisprudenciales supranacionales que he mencionado hasta aquí, también lo son esos otros conceptos que la propia Corte Interamericana incluyó en su propia construcción del control interno de convencionalidad.

Me estoy refiriendo a la siguiente expresión empleada por la CorteidH: la función de control de convencionalidad -se dijo en la sentencia del caso Trabajadores Cesados del Congreso- "no debe quedar limitada exclusivamente por las manifestaciones o actos de los accionantes en cada caso concreto, aunque tampoco implica que ese control deba ejercerse siempre, sin considerar otros supuestos formales y materiales de admisibilidad y procedencia de ese tipo de acciones".

El párrafo anterior, que forma parte del pronunciamiento de la Corte Interamericana para el diseño del control interno de convencionalidad, incluye de nueva cuenta elementos inamovibles y elementos sujetos a las determinaciones internas. Por lo que toca al primer supuesto -contenido en la porción inicial del párrafo transcrito-, el tribunal supranacional reitera que no es preciso que el presunto lesionado invoque la protección del órgano jurisdiccional que conoce las alegadas violaciones para que éste aplique sus poderes y declare la existencia de una violación y las consecuencias de ésta. Viene al caso una aplicación más del principio jura novit curia, ampliamente transitado por la jurisprudencia internacional e insistentemente recogido por la interamericana a partir de los primeros pronunciamientos en asuntos contenciosos. Puesto en otras palabras, el control se ejerce ex officio, con entera independencia de que lo invoquen o no los agraviados.

El segundo supuesto, incluido en la parte final del mismo párrafo transcrito, remite a la existencia de posibles presupuestos formales y materiales de admisibilidad y procedencia. Sabemos, como antes manifesté, que la propia normativa internacional dispone ciertos presupuestos para la apertura y el desarrollo de la via internacional de protección de los derechos humanos: condiciones materiales y formales (relacionados con la naturaleza de la cuestión, la oportunidad en la presentación del asunto, la competencia del órgano, por ejemplo), ante la Comisión y ante la Corte.

La exigencia de que se satisfagan estos presupuestos no implica de suyo, en el caso concreto en el que se plantean, apreciación sobre la existencia de las violaciones aducidas o la responsabilidad de quien deba enfrentarlas o la reparación pertinente. Sólo significa - pero esto no carece de importancia y trascendencia, casuísticamente, como es evidente- que el despliegue de la vía internacional, en su caso, y del control interno de convencionalidad, en el suyo, se hallan asociados a la observancia de esos presupuestos. Desde luego, la normativa interna 
puede ser -e incluso debe ser- muy favorecedora de la tutela de los derechos fundamentales, y por ende puede y debe reducir al mínimo los citados presupuestos, a fin de no oponer barreras innecesaria a la protección del individuo. Bajo la misma lógica se prevén los presupuestos en el ámbito internacional.

\section{Posición de la Suprema Corte de Justicia de México}

En la obra redactada conjuntamente por el autor de estas líneas y Mauricio del Toro, México ante la Corte Interamericana de Derechos Humanos, y en la elaborada, también conjuntamente, con Julieta MoRAlES SÁNCHEZ, La reforma constitucional sobre derechos humanos (2009-2011), ambas citadas en otra parte del presente estudio, se ofrece información y análisis inicial acerca de la posición adoptada por la Suprema Corte de Justicia de México en torno a la materia que aquí examino y a otras, convergentes, relativas a la recepción nacional del derecho internacional de los derechos humanos.

En años recientes se reanimó el planteamiento constitucional de estos temas, tanto a partir de propuestas, que no prosperaron, para la revisión integral del régimen de los derechos humanos previsto en la Constitución de la República, como en torno a la incorporación de nuestro país en el sistema de justicia penal internacional, que determinó adiciones al artículo 21 de la ley fundamental. He manifestado mis puntos de vista en torno a estas adiciones, muy defectuosas, en mi obra La Corte Penal Internacional, editada por el Instituto Nacional de Ciencias Penales.

Lo que me interesa en este momento es mencionar que la iniciativa del Ejecutivo que finalmente condujo -en una versión totalmente distinta- a la modificación del artículo 21, se refirió a las sentencias de tribunales internacionales cuya competencia hubiera aceptado México (a la sazón, la Corte Internacional de Justicia y la Corte Interamericana de Derechos Humanos), e igualmente, aunque no fueron mencionados en la iniciativa, otros órganos ("paneles", por ejemplo) con atribuciones jurisdiccionales y emplazamiento internacional.

Esa iniciativa, de 2001, pretendió establecer los efectos de dichas sentencias en el orden interno, pero no aludió de ninguna manera al control de convencionalidad en el sentido que examinamos ahora. Tampoco lo ha hecho $-\mathrm{y}$ debió hacerlo- la reforma constitucional que culminó en 2011. Mientras ésta se hallaba sujeta a estudio en el Congreso de la Unión y al cabo de su publicación en el Diario Oficial, ya habían surgido en el ámbito jurisdiccional interno algunas interrogantes que pudieron ser materia de la reforma constitucional y que últimamente la justicia mexicana afrontó y resolvió en el espacio de sus propias 
actuaciones. Cuando esto ocurrió, existía ya la inquietud por enfrentar en sentencias judiciales el tema del control interno de convencionalidad, como se vio a través de decisiones de tribunales colegiados, que recogemos en la citada obra sobre México ante la Corte Interamericana de Derechos Humanos. ${ }^{1}$

Recordemos, en síntesis, que la Suprema Corte de Justicia de la Nación debió resolver, al cabo de diversas vicisitudes que no describiré ahora, las derivaciones de la sentencia dictada por la Corte Interamericana en el caso Radilla Pacheco. Así lo hizo, a través de intensas deliberaciones entre el 4 y el 14 de julio de 2011, que pusieron de manifiesto diversos extremos de la recepción nacional y dieron como resultado las decisiones correspondientes al expediente Varios 912/2010. El texto del engrose respectivo fue aprobado el 20 de septiembre de 2011, acompañado por votos emitidos por varios ministros, con alcance personal, y se publicó en el Diario Oficial de la Federación el 4 de octubre de 2011.

A mi juicio, la Suprema Corte dio pasos decisivos y acertados en el examen de esta cuestión. Lo reconozco y celebro, y desde luego comparto varias conclusiones centrales adoptadas por ese tribunal. Había que ir adelante en la reflexión sobre una materia cuyo examen ya resultaba apremiante, y era preciso llevar a cabo la reflexión -con vistas a soluciones integrales futuras- a falta de legislación (constitucional y secundaria) adecuada y suficiente.

De ahí que el alto tribunal fuese mucho más allá del planteamiento original que se hallaba sujeto a su consideración: en sustancia, las implicaciones de la sentencia interamericana para el Poder Judicial de la Federación, como parte del Estado mexicano. La jurisprudencia inició, pues, la solución de problemas que pudo -y debió- anticipar la norma constitucional, aun cuando es cierto -y lo destaco- que la reforma de 2011 a la ley suprema ofreció un marco muy favorable al oportuno debate en la Suprema Corte de Justicia de la Nación.

Creo útil transcribir aquí -como anuncié al inicio de este trabajo- algunos criterios adoptados por la Suprema Corte en la decisión que concluye el examen del expediente Varios 912/2010. Hago notar que no se trata de una sentencia en amparo, en acción de inconstitucionalidad o en controversia constitucional. El pronunciamiento posee otra naturaleza jurídica, de la que derivan sus efectos. Se ha considerado que recoge decisiones orientadoras. Es, sin duda, fuente favo-

1 Control de convencionaldad en Sede interna. Los tribunales mexicanos están obligados a aejercerlo. Semanario Judicial de la Federación y su Gaceta, Novena Época, TCC, t. xxXI, mayo de 2010, y Control de CONVENCIONALIDAD. Debe SER EeRRIIDo POR LOS

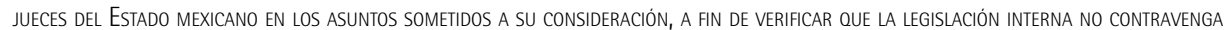
el objeto y finaldida de la Convención Americana sobre Derechos Humanos. Semanario Judicial de la Federación y su Gaceta, Novena Época, TCC, t. XXXI, marzo de 2010, p. 2927. SeRna de LA GarZA menciona y elogia una sentencia dictada por el magistrado estatal de Nuevo León, Carlos Arenas, después de la reforma constitucional y las decisiones de la Suprema Corte de Justicia, de 2011, que inaplicó un tipo penal contenido en el código de la materia de esa entidad federativa, por considerarlo contrario a la Constitución mexicana y a las normas internacionales sobre derechos humanos. 
recedora o determinante para decisiones judiciales, administrativas y legislativas, que necesariamente habrá de instalarse sobre los criterios adoptados por el alto tribunal de la República.

Mencionaré las determinaciones de la Corte en el orden en que aparecen en el documento de engrose del 20 de septiembre de 2011. No incluiré, por supuesto, las consideraciones respectivas ni referencias al debate; tampoco daré noticia de la votación específica en cada caso. Las determinaciones que transcribo, establecidas en la porción resolutiva del documento que las contiene, son las que merecieron mayoría o unanimidad de votos.

a) La Suprema Corte no es competente para revisar, ante las sentencias condenatorias emitidas por la Corteidh, "si se configura alguna de las excepciones del Estado mexicano al reconocimiento de la jurisdicción contenciosa de aquélla, o alguna de las reservas o declaraciones interpretativas que formuló" al adherirse a la CADH o a la Convención Interamericana sobre Desaparición Forzada de Personas.

b) Las sentencias condenatorias de la CorteidH "son obligatorias para el Poder Judicial de la Federación en sus términos".

c) Los criterios interpretativos de la CorteidH "son orientadores para el Poder Judicial de la Federación".

d) De conformidad con el párrafo 339 de la sentencia de la CorteidH en el caso Radilla Pacheco, el "Poder Judicial de la Federación debe ejercer un control de convencionalidad ex officio entre las normas internas y la Convención Americana, en el marco de sus respectivas competencias y de las regulaciones procesales correspondientes".

e) "El control de convencionalidad debe ejercerse por todos los jueces del Estado mexicano".

f) El modelo de control de convencionalidad y constitucionalidad que debe adoptarse es en el sentido de que:

1) Los jueces del Poder Judicial de la Federación, al conocer de controversias constitucionales, acciones de inconstitucionalidad y de amparo, pueden declarar la invalidez de las normas que contravengan la Constitución federal y/o los tratados internacionales que reconozcan derechos humanos; 2) los demás jueces del país, en los asuntos de su competencia, podrán desaplicar las normas que infrinjan la Constitución federal y/o los tratados internacionales que reconozcan derechos humanos, sólo para efectos del caso concreto y sin hacer una declaración de invalidez de las disposiciones, y 3) las autoridades del país que no ejerzan funciones jurisdiccionales deben interpretar los derechos humanos de la manera que más los 
favorezca, sin que estén facultadas para declarar la invalidez de las normas o para desaplicarlas en casos concretos.

g) "Los párrafos 337 a 342 de la sentencia emitida por la Corte Interamericana de Derechos Humanos en el caso Radilla Pacheco vs. Estados Unidos Mexicanos, resultan obligatorios para los jueces del Estado mexicano, al ejercer el control de convencionalidad".

h) "Los jueces del Estado mexicano deberán reiterar en los casos futuros el criterio de la Corte Interamericana de Derechos Humanos sobre la restricción del fuero militar, en cumplimiento de la sentencia que emitió en el caso Radilla Pacheco vs. Estados Unidos Mexicanos, y en aplicación del artículo $1^{\circ}$ constitucional".

i) La Suprema Corte de Justicia "deberá reasumir su competencia originaria para resolver los conflictos competenciales que se presenten entre la jurisdicción militar y la ordinaria”.

j) El Poder Judicial de la Federación deberá establecer cursos de capacitación en diversos campos atinentes a la protección internacional de los derechos humanos -que la decisión de la Suprema Corte señala con detalle- destinados a jueces, magistrados y funcionarios públicos que realicen labores jurisdiccionales y jurídicas del Poder Judicial de la Federación.

k) "El Poder Judicial de la Federación debe garantizar que la averiguación previa [...] respecto al caso Radilla Pacheco se mantenga bajo conocimiento de la jurisdicción ordinaria y bajo ninguna circunstancia en el fuero de guerra".

1) En virtud de que "todos los jueces del Estado mexicano [...] están facultados para inaplicar las normas generales que a su juicio consideren transgresoras de los derechos humanos contenidos en la propia Constitución federal y en los tratados en materia de derechos humanos, resulta necesario que el Tribunal Pleno modifique la jurisprudencia P./J. 74/1999”.'

\footnotetext{
2 Esta jurisprudencia, que manifiesta la posición de la Suprema Corte de Justicia hasta antes de las decisiones de julio de 2011, y que estuvo precedida por definiciones del más alto tribunal en sentido diferente, se expresa en los siguientes términos: "Control difuso de la Constitucionaldad de normas generales. No lO aUtoriza el artículo 133 dE LA Constitución. El texto expreso del artículo 133 de la Constitución federal previene que [...] En dicho sentido literal llegó a pronunciarse la Suprema Corte de Justicia; sin embargo, la postura sustentada con posterioridad por este alto tribunal, de manera predominante, ha sido en otro sentido, tomando en cuenta una interpretación sistemática del precepto y los principios que conforman nuestra Constitución. En efecto, esta Suprema Corte de Justicia de la Nación considera que el artículo 133 constitucional, no es fuente de facultades de control constitucional para las autoridades que ejercen funciones materialmente jurisdiccionales, respecto de actos ajenos, como son las leyes emanadas del propio Congreso, ni de sus propias actuaciones, que les permitan desconocer unos y otros, pues dicho precepto debe ser interpretado a la luz del régimen previsto por la propia carta magna para ese efecto". Semanario Judicial de la Federación y su Gaceta, Novena Época, Pleno, vol. x, agosto de 1999, p. 5.
} 
SERGIO GARCÍA RAMÍREZ

m) "El Poder Judicial de la Federación adecuará sus subsecuentes interpretaciones constitucionales y legales sobre la competencia material y personal de la jurisdicción militar, orientándose con los criterios contenidos en la jurisprudencia de la Corte Interamericana de Derechos Humanos".

n) "De acuerdo con los párrafos 252 y 256 de la sentencia de la Corte Interamericana de Derechos Humanos en el caso Radilla Pacheco vs. Estados Unidos Mexicanos, deberá garantizarse en todas las instancias conducentes, el acceso al expediente y la expedición de copias del mismo para las víctimas".

ñ) "La Suprema Corte de Justicia deberá reasumir su competencia originaria o ejercer la facultad de atracción para conocer de conflictos competenciales entre la jurisdicción militar y la ordinaria, o bien, ejercer de oficio su facultad de atracción por tratarse de un tema de importancia y trascendencia, por tanto, deberá solicitar a todos los juzgados y tribunales federales del país, que en el caso de que tengan bajo su conocimiento algún asunto relacionado con el tema, lo informen a [la] Suprema Corte para los efectos anteriores".

Ya he expresado mi parecer sobre varios temas abarcados por estas determinaciones de la Suprema Corte de Justicia, entre ellos los correspondientes a la eficacia vinculante que poseen, en mi concepto, los criterios adoptados por la CorteIDH cuando actúa como intérprete de la Convención Americana -que es, a su turno, una normativa vinculante para los Estados partes, entre ellos México-, independientemente de que se hallen depositados en una resolución concerniente a nuestro país o a otro Estado parte en el sistema interamericano.

También he señalado mi punto de vista acerca del control judicial interno de convencionalidad, para que éste satisfaga los fundamentos que lo sustentan y los objetivos a los que atiende, y se despliegue -como lo ha manifestado explícitamente la CorteIDH, cuyos pronunciamientos a este respecto determinaron las decisiones de la Suprema Corte de Justicia de la Nación- conforme a la competencia que se asigne a los tribunales que ejerzan el control y a los procedimientos establecidos para ello.

Concluiré esta revisión en torno al control judicial interno de convencionalidad con las palabras que figuran al final del libro México ante la Corte Interamericana de Derechos Humanos:

Una vez cumplida la reflexión judicial sobre estos temas, conviene que en el futuro inmediato se produzca el debate legislativo y la aprobación de normas específicas que definan claramente los procedimientos para el cumplimiento, por parte de los 
diferentes órganos del Estado, de la CorteidH y de otras instancias y tribunales internacionales, así como el diseño que garantice en el marco del complejo sistema judicial mexicano, un adecuado control de convencionalidad, sin generar desequilibrios innecesarios en el modelo de justicia interna.

Apremia, pues, el trabajo legislativo; sin éste, se mantendrá inconclusa la tarea emprendida por la Suprema Corte para recibir internamente el derecho internacional de los derechos humanos, y tampoco ganará en homogeneidad y claridad el ingreso al orden jurídico mexicano de los derechos previstos en convenciones internacionales, como lo postula el nuevo texto del artículo $1^{\circ}$ constitucional. 